\title{
MANAGING SUSTAINABLE TOURISM IN THE CONTEXT OF CHANGING CONSUMER BEHAVIOUR AND CONSUMER VALUE
}

\author{
Daiva Labanauskaité ${ }^{1}$, Deimena KiyaK ${ }^{2}$, Dovilè Bagočıūté ${ }^{3}$ \\ Klaipėda University (Lithuania)
}

\begin{abstract}
Changes caused by globalization changed consumer behaviour. It is passed from the era of items to the era of services causing emotions. On the other hand, it's still a speculation, whether globalization affects the behaviour of Lithuanian people in choosing tourism. The research found that the Lithuanian residents still live in the era of items. For them is most important material safety and image through items. To meet these needs Lithuanian residents prefer traveling abroad. Outbound tourism is attractive for the population of Lithuania, but they frequently travel in Lithuanian territory. Lithuanian tourists are planning travel usually by themselves; this process is combined with rational. Economic, demographic and cultural factors have the greatest influence on the choice of Lithuanians to make trips. Social, psychological and situational factors in the marketing mix have less impact.

KEYWORDS: consumer, consumer behaviour, sustainable tourism.
\end{abstract}

JEL CODES: O100, O110, L890

\section{Introduction}

Globalization changes affected consumer behaviour, so these days users dream of good life, which expresses itself through the need for emotions, experiences. In other words it is passed from the "era of items" to the "era of services causing emotions". The concept of "a consumption, causing experiences" entrenches instead of „,consumption for consumption. Consumer society itself is increasingly expressed not through things, but in the amounts of travel and entertainment. It can be said that these days a consumer is a traveler, and for those who do not travel it is difficult to fit into modern consumer stereotypes.

According to T. C. Human and J. Beat (Moutinho, Ballantyne, Rate, 2009: 85) the model of tourism consumer behaviour is based on a person's character, attitudes, values, socio-demographic factors, experience and information. A modern tourist is unique, it is difficult to assign somebody to traditional segment. Tourists pay a lot to know technologies and are able to adapt in different environments. Given the popular independent travel arrangements, and tourists' love of nature promotes the growth of the value of alternative tourism. It should be noted that presently the last type of tourism has rapidly developed - electronic tourism.

1 Daiva Labanauskaitè - Klaipėda University, Social sciences faculty, Department of Economics, Associated Professor, Doctor for Social sciences. Scientific interests: service economics and marketing, evaluation of business environment E-mail: labanauskaite.daiva@gmail.com

Tel.: 0037068642862

2 Deimena Kiyak - Klaipeda University, Social sciences faculty, Department of Economics, Associated Professor, Doctor for Social sciences. Scientific interests: financial analysis, accounting, pricing methodology

E-mail: deimena@balticum-tv.lt

Tel.: 0037068220253

3 Dovile Bagočiūtè - Klaipèda University, Social sciences faculty, Department of Economics, Master degree graduated student E-mail: do.bagociute@gmail.com

Tel.: 0037065248432 
In a changing world consumer preferences, attempts to determine whether the behaviour of the Lithuanian population characterized by the same features as a global user and maybe Lithuanian population behaviour is influenced by the same factors. Scientific analysis of the sources revealed that consumer behaviour is analyzed quite extensively and on a variety of aspects. Taking into account the arisen problem, it is aimed at combining the thoughts of global scientists into a single whole with the help of the known research methods, to carry out theoretical and practical analysis of the behaviour of tourism consumers, to present a systemized model of the behaviour of a global consumer and to reveal the features of the behaviour of tourism consumer.

The object - Lithuanian population behaviour when choosing tourist services.

The aim - to identify Lithuanian tourists behaviour in choosing tourism services:

- To extract the characteristics of a modern consumer and tourism consumer behaviour.

- To carry out theoretical analysis of factors influencing consumer behaviour.

- To set the Lithuanian population behavioural traits when choosing tourism services.

The problem of the research is associated with the tourists' changing travelling habits and priorities, which leads to the alterations in the popularity of countries on the international tourism market.

Methods of the research: the article is prepared by structuring and generalizing the content of studies carried out by different authors and scholars, and analyzing the tourism development forecasts, by using meta-analysis, correlation analysis, comparison and generalization of systemic methods, interaction factors, and offers modeling, generation of findings, statistical survey data.

\section{Consumers value orientations and consumption patterns change in a modern society}

In order to reduce the negative impact of tourism on the environment, the implementation of sustainable tourism development concept becomes more popular. Sustainable tourism development is perceived as corresponding to the needs of tourists and host regions, protecting from the negative effects of tourism and increasing tourism competitiveness in the future. It is expected that sustainable management of all the resources enables to achieve economic, social and aesthetic needs while maintaining cultural integrity, important ecological processes, biological diversity and life support systems (Sustainable Tourism, 2002: 12).

In order to reduce the negative impact of tourism on the environment, the implementation of sustainable tourism development concept becomes more popular. Sustainable tourism development is perceived as corresponding to the needs of tourists and host regions, protecting from the negative effects of tourism and increasing tourism competitiveness in the future. It is expected that sustainable management of all the resources enables to achieve economic, social and aesthetic needs while maintaining cultural integrity, important ecological processes, biological diversity and life support systems (Sustainable Tourism, 2002: 18).

Sustainable tourism development guidelines and management practices are applicable to all forms of tourism in all types of popular destinations, including mass tourism and the various niche tourism segments of the market. Sustainable development principles apply to the development of environmental, economic as well as social and cultural aspects of tourism, and the right balance must be established between these three dimensions to ensure their long-term sustainability. Sustainable tourism development concept encourages:

- Optimal use of natural resources, which form the basis of the development of tourism, while maintaining essential ecological processes and helping to preserve natural heritage and biodiversity.

- Respect the host communities, socio-cultural authenticity, while maintaining their designed life of cultural heritage and traditional values, and contribute to inter-cultural understanding and tolerance.

- Ensure effective, long-term economic operations, providing socio-economic benefits to all parties that it would be fairly distributed, including stable host communities employment and income opportunities, social services, and thus contribute to poverty reduction (Neto, 2002: 43). 
It was found that the success of the concept of sustainable tourism development is a precondition integrated approach to tourism development and tourism activities in the process of direct and indirect participants in collaboration and co-operation policies (McKercher, 2003: 83):

- activities and ecological diversity transmission from generation to generation;

- conditions in the community to enjoy life assurance;

- $\quad$ public participation;

- protection of the environment as an economic development component;

- caution in respect of risk and unawareness;

- increasing employee, community, operator and guest awareness and understanding of the natural and cultural heritage.

Implementation of the results of the fundamental concept of sustainable tourism development includes increased tourism development issues in constructive, higher local residents support for tourism business development and more favorable treatment, higher quality tourism products, the minimum and managed tourism activities on the environment.

According to the concept of sustainable tourism development, tourism contribution to the creation of income and employment is no longer a major impact on tourism in the region to assess the economic indicators. Application of the concept of sustainable tourism development, the main focus is not on maximizing revenue in the short term, but on the sustainability of the tourism industry in the long term.

Human like consumer behaviour analysis has changed since the beginning of market. Consumer values, needs and behaviour change in the context of changing social, economic, political and other developments. It is often said that in order to know the current consumer, it is necessary to analyze the past behaviour of consumers and their characteristics. All of what is now, there is nothing else than the historical improvement. In this context, it is important to review the changes in consumer behaviour and become familiar with the concept of the current user.

Analyzing the changes in consumer behaviour trends, several stages in the evolution of consumer behaviour can be distinguished: Pre-disciplinary (until 1960). Evolutionary (1960-1974), Cognitive (1975-1981), Modern level (1981-1991), Late modern (since 1991) (See Table 1).

Table 1. Stages of consumer behaviour

\begin{tabular}{|l|l|l|}
\hline $\begin{array}{c}\text { Stages of } \\
\text { consumer } \\
\text { behaviour }\end{array}$ & \multicolumn{1}{|c|}{ Period } & \multicolumn{1}{c|}{ Characteristic of consumer behaviour } \\
\hline Pre-disciplinary & until 1960 & $\begin{array}{l}\text { Consumers purchasing a product or service discussed about the future. This } \\
\text { is a timeshare of Fordism }\end{array}$ \\
\hline Evolutionary & $1960-1974$ & $\begin{array}{l}\text { Behaviourism dominated - human reaction to various external environmental } \\
\text { changes }\end{array}$ \\
\hline Cognitive & $1975-1981$ & $\begin{array}{l}\text { Great attention is paid to the purposes of consumer needs and buying } \\
\text { behaviour analysis. A consumer was considered to be a rational being who is } \\
\text { trying to solve his problems by processing information carefully and taking } \\
\text { logical decisions }\end{array}$ \\
\hline Modern & $\begin{array}{l}\text { A consumer became modern. Consumer emotions and information retrieval } \\
\text { played an important role. Users began to search for a product, taking into } \\
\text { account not only the price but also the quality, external image, impression, } \\
\text { flavor, and so on. Increasing importance of the phenomenon has become } \\
\text { one - not a product / service, so the company had to follow the motto "closer } \\
\text { to the user" }\end{array}$ \\
\hline
\end{tabular}




\begin{tabular}{|c|c|c|}
\hline $\begin{array}{c}\text { Stages of } \\
\text { consumer } \\
\text { behaviour }\end{array}$ & Period & \multicolumn{1}{c|}{ Characteristic of consumer behaviour } \\
\hline Late modern & Since 1991 & $\begin{array}{l}\text { Public wealth grows, so its representatives can spend more money on } \\
\text { goods, leisure, holidays, and other higher level applications. It is a society } \\
\text { in which employment declines and leisure budget increases; individual } \\
\text { identity is constructed by the use and free time. Increasingly aestheticised } \\
\text { life, consumers tend to construct distinctive ways of life, while consumption } \\
\text { is constructed according to certain imaginary models. It is a society where } \\
\text { consumption, lifestyle, acquisition of certain goods are increasingly } \\
\text { becoming indicators of a social position }\end{array}$ \\
\hline
\end{tabular}

Source: Davies, Elliott, 2006: 110; Skrudupaitè, Virvilaitè, Kuvykaitè, 2006: 74; Virvilaitė, Banytė, 2000: 59; Zinkevičiūtè, Kazlauskas, Birgelytè, Olberkytè, 2010: 206

The descriptions in the table 1 note that a neutral and trusting customer is gradually becoming a modern consumer who has knowledge and analyzes their needs and supply options. The changing socio-economic environment has an impact on consumer behaviour, and changing user needs and priorities.

Globalization makes a substantial impact on the development of a customer. The increasing mobility of people and power of press, flow of information is growing rapidly, people are developing (Vosyliute, 2008: 393). The media, online sites and social networks encourage consumers to know their rights and duties, teaches to save money. Web sites are full of tips, training, discussion and support websites, which enable users to progress. Development of people from the low-end consumer habits moves to a user of higher classes. In other words, a consumer is becoming educated and aware of his/her value.

Web sites allow for customers not only to search for educational material, but also to compare the prices of goods and services. It should be noted that in the medium and upper social class Europeans, buying everyday goods tend to save and often shop across Europe wide-spread supermarkets. A space of a customer extends from the local to the global market, the whole world market. Using the internet a customer can order a desired product from any country in the world, or go on a trip to buy goods from another country. This phenomenon of a purchase was little used in practice few years ago and is now becoming commonplace.

On the other hand, in order to emphasize the exclusivity and their social status in the society, the same saves customers chasing famous brands. Trademark users become "above all". A large number of social research, which has shown that consumers highly recognize brands, but does not distinguish between the leaves of trees, plants and so on. In other words, we live in an era of brands. In addition, according to A. Skrudupaite, R. Virvilaite, R. Kuvykaite (2006: 78), a lot of money are spent on leisure, entertainment, pleasure and travel.

On the conditions of expansion of customers space can be said that these days a customer cannot imagine his/her life without abundant goods and services. This is encouraged by higher product / service supply growth, newly introduced products and brands. According to A. Davies, R. Elliott (2006: 1114-1116) major changes in consumer behaviour brought the opportunity to purchase goods or services on credit. The chance to buy goods on a bank loan, a luxury brand that was affordable only to a higher social class and higher income earners have become affordable for most. As a result, people began to consume more.

Advanced consumers use the expansion of space and the potential for goods or services purchased in installments, but slowly began to emerge surrounding the impact on consumption. Experts releases a key and these days the most determinant of consumer behaviour - the surrounding affected. People are trying to work together and keep up with each other. One person's choice and behaviour becomes another person and purpose of the stimulus (Moutinho, Ballantyne, Rate, 2009: 85). People do not want to fall behind each other, do not want to be worse, or look poorer, making an effort to be "the same" or purchase "better" than what you already have. This phenomenon is more prevalent among the middle class. Upper-class people have exclusive opportunities for their usual means ostentatiously over large sums of money. 
In summary, the stages of consumer behaviour perfectly reflect changes in consumption. Login evolution becomes demanding, emphasizing their social status, responsive marketing tools and brand influence. It is passed from a rational consumption to "consumption now" without thinking about the future. Low-end consumer habits shift to the higher classes of consumption. Apparent consumption is leveling the surrounding. Based on the use of technology extends the limit - from local to global consumer shift. The possibility of a global market for goods or services purchased cheaper, loan options and the growing consumer demand are increasing. Consumers are increasingly taking over the foreign values, culture, traditions and behaviour. It can be argued that a modern consumer is slowly transforming into a global, or "new era" consumer, but the consumer's behavioural traits are still faintly discerned by scientific literature and not largely analyzed.

\section{Changing consumer behaviour in the global tourism Market}

The analysis of changes in the structure of consumer market shows the increasing leisure budget. Leisure time activities have evolved along with the change in social, economic, technological and other factors.

According to A. Vosyliute (2008: 395), tourism combines different seekers, people, characters, places, behaviour, and it is the foundation of all the tourists. According to C. Cooper, J. Fletcher, D. Gilbert, S. Wanhill, McDonald and others. (2003), tourism is important for nations lives as a direct result of social, cultural, educational and economic spheres of human and international relations (Cooper, Fletcher and others, 2007: 62). In other words, tourism is a measure of the population and the development of international cooperation between countries through the tourists. Consumer needs have changed over the past decade with the growing influence of interest groups and thus the concept of tourism itself evolved. According to R. Dapkus G. Gaižauskiene (2009: 61), the tourism market is an elite occupation and it has become a mass phenomenon. Touring model has also changed. In Soviet times, traveling abroad was seen as the acquisition of goods and now a trip is associated with signs, symbols, culture (Vosyliute, 2008: 397). According to B. McKertcher H. du Cros (2002: 215) above were traveling on sightseeing purposes, access to the history of the churches, temples. These days, traveling purposes become entertainment, leisure and travel-European rail system, ferries, etc. (Cooper, Fletcher, and others, 2007: 64).

Also, GDP growth, infrastructure change, a constant development of a country to expand educational and cultural horizons and "vaccine" sense of self-esteem, quality of life improvement from higher income and better living standards, dissociation of language, social, class, race, political and religious barriers and promote cooperation between the peoples of the world are driven by tourism development (Goeldner, Ritchie, 2008). Lifestyle changes, reduced working hours, higher income from own businesses, a significantly higher value of leisure, nature conservation and other consumer behaviour has led opposition to mass tourism and the emergence of new tourism industries (Pearce, Butler, 1989: 17).

It should be noted that even in the seventies of the twentieth century consumption of consumer philosophy formed in developed countries. The last decade of the twentieth century was a shift from the pipelined nature of tourism, where travelers meet the needs of mass pipelined nature, offers to a tourist a differentiated model that started to emerge in the tourism individualization direction are exposed to a brighter economic humanization, socialization and ecologic trends when the public spotlight once again in the personality of their needs' spectrum. Therefore, instead of "consumption for consumption" there entrenched a philosophy of "consumption, which causes experiences", when a commodity or a service is purchased because its consumption enables to experience new impressions and helps to gain a new individual experience (Cepaitiene, 2011: 149).

It was intended that the new types of tourism take into account the growing number of responsible tourists who perceive the tourism concept itself as an environmentally friendly system with identifiable environmental, economic, and social responsibility (Zinkevičiūtè, Kazlauskas, Birgelyte, Olberkyte, 2010: 205). In the context of mass tourism criticism in the seventies - eighties of the twentieth century, a term "alternative tourism" was started to be used (Knowles, Diamantis, Ell-Mourhabi, 2004: 12). This is one of the most widely used phrases of modern tourism literature. Alternative tourism generated around the concept of a range of 
tourism, as "integrated", "sustainable", "eco", "soft", "responsibility", "control", "small-dimensional", the new, "green", "special interests" and so on (Zinkevičiute, Kazlauskas, Birgelyte, Olberkyte, 2010: 206). Currently another type of modern tourism has developed - an electronic tourism. Web sites, social networking and other communication with the help of foreign users can communicate with the other country a personal exchange of information about the country, photographs, share cultural values, lifestyle, traditions and so on (Smith, Macleod, Hart, Robertson, 2010: 57).

It should be noted that the growing importance of tourism has made the greatest impact on consumer thinking and behaviour (Brent Ritchie, Hudson, 2009: 119). Changing consumer behaviour has developed a new description of a tourist - a tourist is a very educated, knowledgeable, experienced person and has much higher expectations than ever before. A tourist is an individual, it is difficult to assign somebody to traditional segment. Usually tourists are frequent travelers. S/he knows a lot of technologies, and is able to pay and adapt to different cultural environments (Moutinho, Ballantyne, Rate, 2011: 85). Behaviour model of a tourism consumer, according T. C. Human and J. Beats, is based on internal personal qualities, attitudes, values, socio-demographic factors, experience and information (Moutinho, Ballantyne, Rate, 2011: 85).

It can be argued that the main purpose of tourist traveling - is searching for another culture, the attempt to exchange experiences, to communicate with other citizens of a new environment and seeking experience. Culture and Society, which develops the culture, is a major tourist attraction. Tourists from developed countries especially like to access smaller countries' traditions, customs, language, crafts, food, music, art and architecture (Williams, 2009: 134; Coathup, 1999; Cooper, Fletcher and others, 2007: 62). Regardless of the type or time of travelling, tourists seek to enjoy nature and to experience some long-lasting emotions. Therefore ethical and responsible travel is popular (Moutinho, Ballantyne, Rate, 2011: 85; Tribe, 2009: 28). It outgrows the need for self-organization of travel (DIY packaging by consumer), there is an increasing number of short but frequent travels and the number of long travels decreases (Tribe, 2009: 28). The trend of total income growth enables more individuals and families to travel long distances (Makauskiene, Giziene, 2011: 216).

The biggest challenge for travel agents is that future tourists will pose even greater demands, will want even more senses, and all of the companies insist on honesty and simplicity. This means that companies will have to change the presentation of tourism services, as experienced, cynical, marketing savvy users will be impressed just hard to brand names or trademarks, they will need much more (Moutinho, Ballantyne, Rate, 2011: 85). Significant added value to the user can provide a service speed, connectivity, communication, experience sharing, and so on.

In summary it can be said that tourism, as a pastime, at all times remains attractive, but the value and benefits of tourism are changing. Changing needs of users from mass tourism has shifted to the individual. The rapidly growing significance of tourism has changed the consumer behaviour. Changing consumer behaviour has developed a new description of a tourist - a tourist is a very educated, knowledgeable, experienced and has much higher expectations than ever before. S/he knows a lot of technologies, and is able to pay and adapt to different cultural environments. In view of the growing self-planned trips, a tourist seeks to rest, to enjoy nature, to experience some long-lasting emotions. Given the growing importance of alternative tourism, it should be noted that there is a progressive, new type of tourism - an electronic tourism. However, the etourism literature deals with still very few and far between customers and the company of this phenomenon still are unaware of that.

\section{Analysis of changes in Lithuanian tourists behaviour and values}

Following the theoretical analysis of the factors influencing consumer behaviour it was found that socioeconomic factors have the greatest influence on consumer behaviour. Based on the theoretical analysis it cannot be determined what factors influence the behaviour of Lithuanian tourism consumer.

In this context, this research and one on whether Lithuania travel consumers prefer local or outgoing 
tourism, which Lithuanian tourism consumer behaviour traits become apparent when selecting tourism services, it is aimed at finding out the tourism consumer behaviour and to identify the factors that influence consumer behaviour in choosing tourism services.

The aim of research - to analyze the behavioural traits of Lithuanian population when choosing tourism services.

The object of research - the behaviour of Lithuanian population when choosing tourism services.

Objectives of research:

- To figure out tourism popularity among Lithuanian consumers.

- To expose what behavioural features Lithuanian population revealed in choosing tourism services.

- To determine what factors influence the behaviour of Lithuanian population when choosing tourism services.

The research hypothesis:

- Lithuanian population gets more profit from leisure than material things. In other words the era of items passes to the leisure era.

- Lithuanian outbound tourism market increases the number of self-planned trips.

- Selection of outbound tourism services is mainly determined by socio-economic factors, including age, income, education.

Method of research: survey using a questionnaire.

The majority of 426 respondents disagree with the statement that entertainment can be found only in their city, so they choose trips. Retired people tend to entertain in their city and repair housing rather than travel. Traveling is not an every year tradition and a way of life for respondents. Constant travel is relevant for a population in the age of $19-25$ years.

Travelling within Lithuania is more frequent than outside Lithuania. Outbound tourism is more relevant than local tourism for persons under 50 years, respondents older than 50 years give priority to travel in Lithuanian territory.

Countries most frequently visited by respondents - Latvia, Poland, Germany, Italy, France, Czech Republic, Estonia. These countries are intensively promoted and easily accessible by private transport, bus, ferry, train or plane and is quite cheap in comparison with Switzerland, Norway and so on. The most common purpose of a journey is to the distant, cheap and widely promoted countries (Latvia, Poland, Germany, Italy, France, Czech Republic, Estonia).

Summarizing the results, it is noted that participants of the research travel when they feel financially secure and do not tend to travel if they have to borrow money from friends or banks. The participants of the research rationally choose tourism services. Lithuanian residents often purchase cheap airline tickets, stay in medium-sized hotels or (where possible) visit friends, relatives or acquaintances. These are trips when Lithuanians spend small amounts of money. Not only young but also older people save money. Most of the population of Lithuania saves by planning trip themselves. This behaviour leads to rising level of computer literacy and technology options.

Mostly traveling is not the purpose of life, tradition or social status expression. On the other hand, social status of the ones who travel show that mostly they are persons from 36 years up to retirement, whose (or their family's) monthly income is higher than $5000 \mathrm{Lt}$, especially men.

The results revealed that the main priority of the respondents (as opposed to a global user) - is material security. Lithuanian residents dream of travelling outside Lithuania, but in fact only a very small part of the population does.

Lithuanian residents travel to relax. Young people go on trips to find adventure. Higher educated individuals try to discern scientific and business-friendly benefits, so they save when choosing a trip.

Lithuanian residents still underestimate the importance of eco-friendly tourism. The majority of respond- 
ents stated that they travel in Lithuania and abroad, the number of the amount of money paid to travel these days has not changed compared to the pre-crisis and crisis period. Also unchanged remain distances, time, vacation time, travel booking through agencies, independent travel, travel by private transport. On the other hand, the linear correlation method showed that the growth of GDP, employment, wages, income, and inflation in the number of trips abroad had to increase. With the increase in prices of the essential commodities and services, Lithuanian residents say that they will continue traveling, but they will choose cheaper trips.

The choice of travel destinations is determined by the purpose of a trip, special offer, price, visited historical objects, recreational quality and entertainment in the country. Travel distance, duration, cheap food in the country, friends' recommendation, and marketing tools have only a small impact on choosing a country. On the other hand, there are many marketing tools promoting Lithuanian residents to travel, or to think about travel. Attitudes and special "good offers" have the greatest influence on 19-25 year olds and retired people. Mostly the choice of tourism services is influenced by saving and lifestyle traditions passed on from generation to generation as well as age and income. Having prioritized, a Lithuanian resident follows travel offers and at some point becomes sensitive to marketing factors.

\section{Conclusions}

Talking about the behaviour of tourism consumers it was determined that the philosophy of "a consumption, causing experiences" has taken root instead of "consumption for consumption". A new tourist is described as an educated, experienced and has much higher expectations than ever before. He is more aware of using technologies and is able to adapt to different cultural environments. As a result, the number of selfplanned trips and popularity of e-tourism increases. These days, people from towns increasingly value nature, which results in an increased importance of alternative tourism. The main purpose of travel is becoming the new environment and experience associated with the quest for signs, symbols and culture. It can be said that these days a tourist is an individual, it is difficult to assign somebody to traditional segment.

Consumer behaviour is influenced by economic, psychological, personal, demographic, socio-cultural, situational, technological and marketing factors. The strength of factors affecting consumer behaviour depends on the situation, product, age, gender and so on. It is also good to know that a user examines the events of the past, and it prolongs the process of problem recognition and decision-making. As for the factors affecting tourism consumer behaviour, it was found that the influence on the choice of tourists was started by ongoing marketing communication factors and the growing quality of tourism products (services). Tourism consumer behaviour is also determined by household composition, housing area, modern communication facilities (Internet). GNP growth, continuous development of the country, to expand educational and cultural horizons, improved quality of life, the transition to higher income and better living standards, dissociation of the language, social, class, race, political and religious barriers to encourage the development of tourism.

The results revealed that the main priority of the Lithuanian population (as opposed to a global user) - is material safety. The era of items still prevails in Lithuania. Lithuanian residents dream of traveling outside of Lithuania, but in fact a very small part of the population goes somewhere. Lithuanians travel more often in Lithuanian territory than outside Lithuania. The most common purpose of journey are becoming distant, cheap and widely promoted countries. Lithuanian tourists are thrifty, so when planning travel and accommodation choices they are looking for the cheapest alternative. They increasingly plan trips themselves. Lithuanian residents still underestimate the importance of eco-friendly tourism. The majority of respondents stated that the number of travels in Lithuania and abroad as well as the amount of money allocated to travelling haven't changed comparign the present situation to the pre-crisis or crisis periods. Travel distances, duration, holiday period, ordering trips through agencies, independent travelling, travelling by private transport also haven't changed. On the other hand using a linear correlation method it was determined that with the increase in GDP, employment, salary, income and inflation, the number of trips abroad had to increase. With the increase in prices of essential goods and services, Lithuanian residents say that they will continue 
travelling, but will choose cheaper trips.

Mostly the choice of tourism services is influenced by saving and lifestyle traditions passed from generation to generation as well as age and income. Having prioritized, a Lithuanian resident follows travel offers and at some point becomes sensitive to marketing factors. It should be noted, that it is not enough to sell a product, it is important to provide added value - information on places of interest, insurance, renting a car in the country, and so on. When transferring an information message it is important to orientate oneself towards certain segments, to choose certain slogans and invocations. The marketing activities are extremely important to continuously monitor changes in consumer behaviour, needs. When implementing marketing activity it is especially important to constantly observe the changes in consumer behaviour, their needs and accordingly to select a suitable means of communication with a consumer.

\section{References}

Brent Ritchie, J. R., Sun Tung, V. W., Robin, J. B. Ritchie. (2011). Tourism experience management research: Emergence, evolution and future directions. International Journal of Contemporary Hospitality Management, Vol. 23, Issue 4, p. 419-438.

Charles, R. Goeldner, J. R., Brent R. (2008). Tourism: principles, practices, philosophies. eISBN: 978-0-470-44060-5. Website: http://www.google.lt/books?hl=lt\&lr=\&id=V495NkYmOn8C\&oi=fnd\&pg=PT9\&dq=tourism\&ots=ik93 KCtSxc\&sig=PDMyWIPVCK4JKaD_MOCMMaRGq5c\&redir_esc=y\#v=onepage\&q=tourism\&f=false $>$

Cooper, C., Fletcher, J., Gilbert, D., Wanhill, S., Cooper, C., Fletcher, J., Gilbert, D., Wanhill, S. (2007). Tourism Principles and Practice. Harlow: Longman. 1996. The influence of the European Union cohesion policy on European tourism destinations Lessons from the Portuguese Algarve for the Bulgarian Black Sea Coast.

Cooper, C., Fletcher, J., Fyall, A., Gilbert, D., Wanhill, S. (2003). Tourism: principles and practice. 4rd edition. Harlow: Pearson Education Limited. Website: <http://www.ukmin.lt/lt/search/simple search.php?search=turizmas>

Čepaitienè, R. (2011). Praeities suprekinimas urbanistinèse erdvėse. Lietuvos istorijos institutas. Urbanistika ir architektūra (Town planning and architecture), Nr. 35 (2), p. 147-158.

Dapkus, R., Gaižauskienè, G. (2009). Turizmo plètros perspektyvos vietos savivaldos lygmeniu. Ekonomika ir vadyba: aktualijos ir perspektyvos, Nr. 3 (16). Website: <http://vddb.laba.lt/fedora/get/LT-eLABa0001:J.04 2010 ISSN_1648-9098.N_3_16.PG_60-72/DS.002.0.01.ARTIC>

Davies, A., Elliott, R. (2006). The evolution of the empowered consumer. European Journal of Marketing, Vol. 40, No. 9/10, p. 18-26.

Makauskienė, A., Gižienè, V. Lietuvos ir Lenkijos pasienio gyventojų turizmo paslaugų ir produktų poreikių tyrimas. Ekonomika ir vadyba, Nr. 16, p. 22-31. Website: <http://internet.ktu.lt/lt/mokslas/zurnalai/eko$\mathrm{vad} / 16 / 1822-6515-2011-0219 . p d f>$

McKercher, B. (2003). Sustainable tourism development - guiding principles for planing and management. Presentation to the National Seminar on Sustainable tourism Development. Bishkek, Kyrgystan, November 5-9.

Moutinho, L., Ballantyne, R., Shirley, S. (2009). USA Context and Dynamics of social Interaction and information search in decision making for Dicretionary travel. Consumer Behaviour in Tourism. 2nd Editon. Website: $<$ http:// www.google.lt/books?hl=lt\&lr=\&id=Jph2vlFmkaAC\&oi=fnd\&pg=PA83\&dq=tourism\&ots=33uKhVqLHr\&sig= VTDTY6qxt9-juLRY5bRYosSqnZc\&redir_esc=y\#v=onepage \&q=tourism\&f $=$ false $>$

Neto, F. (2002). Sustainable Tourism, Environmental Protection and Natural Resource Management: Paradise on Earth? United Nations.

Pearce, G. D., Butler, R. W. (1989). Contemporary Issues in Tourism Development. Website: $<$ http://www.google.lt/bo oks?hl=lt\&lr=\&id=XDa95c6On4YC\&oi=fnd\&pg=PP8\&dq=tourism\&ots=A0fA3Dv4s0\&sig=c2CRMZr8hbrj3Pb oz0fYroIUixE\&redir_esc $=\mathrm{y} \# \mathrm{v}=$ onepage $\& \mathrm{q}=$ tourism $\& \mathrm{f}=$ fals $>$

Skrudupaite, A., Virvilaite, R., Kuvykaitès, R. (2006). Influence of Social Factors on Consumer Behaviour: Context of Euro Integration. Engineering Economics, No. 3 (48). Website: <http://internet.ktu.lt/lt/mokslas/zurnalai/inzeko/48/1392-2758-2006-3-48-73.pdf>

Sustainable tourism. Briefing paper. (2002). Economic Briefing, No. 4.

Tribe, J. (2009). Aspects of Tourism. Philosophical issues in tourism. Website: <http://www.google.lt/books?hl=lt $\& 1 \mathrm{r}=\& \mathrm{id}=3$ XAHXFpPYSIC\&oi=fnd\&pg=PR7\&dq=tourism\&ots=a71tIx5k5r\&sig=2jiKet9qVvQjYhxpdj2d_ $\mathrm{p} 7 \mathrm{KoDE} \&$ redir_esc $=\mathrm{y} \# \mathrm{v}=$ onepage $\& \mathrm{q}=$ tourism $\& \mathrm{f}=$ false

Virvilaitè, R., Banytè, J. (2000). Požiūrio i vartotoju elgsenos tyrimus ištakos ir raida: metodologinis aspektas, 
Nr. 1 (22). Website: <http://info.smf.ktu.lt/Edukin/zurnalas/archive/pdf/2000\%201\%20(22)/5\%20Virvilaite.pdf> Vosyliūtè, A. (2008). Consumption as social problem. Ekonomika ir vadyba: aktualijos ir perspektyvos, Nr. 4 (13), p. 392-397.

Zinkevičiūtè, V., Kazlauskas, V., Birgelytė, A., Olberkytė, L. (2010). Alternatyvaus turizmo Turkijoje problemos ir galimybės Lietuvos vartotojų požiūriu. Verslo ir teisés aktualijos, T. 5.

\title{
DARNIOS TURIZMO PLÉTROS VALDYMAS KINTANČIOS VARTOTOJŲ ELGSENOS IR VERTYBIU KONTEKSTE
}

\author{
Daiva Labanauskaité, Deimena Kiyak, Dovilé Bagočiūté \\ Klaipèdos universitetas (Lietuva)
}

\section{Santrauka}

Globalizacijos nulemti pokyčiai pakeitè vartotojų elgseną. Nuo daiktų eros pereita prie emocijas sukeliančios paslaugu eros. Kita vertus, kaip globalizacija ir darnios turizmo plètros koncepcijos populiarėjimas paveikė Lietuvos gyventojų elgseną, renkantis turizmo paslaugas, vis dar mažai tyrinėta. Šio tyrimo tikslas - nustatyti Lietuvos gyventojų elgsenos bruožus, renkantis turizmo paslaugas.

Atlikus mokslinès literatūros analizę, nustatyta, kad vartotojas evoliucionavo nuo racionalaus, apie ateitị mąstančio vartotojo iki emocingo, turinčio didelių poreikių, svajojančio apie ,gerą gyvenimą“ vartotojo. Nuo žemosios klasės vartojimo îpročių pereinama prie aukštesnių klasių vartojimo ipročių. Žiniasklaidos, internetinių portalų ir socialinių tinklų dẻka vartotojas yra išsilavinęs, savarankiškas, žinantis savo vertę. Pirkdamas kasdienio vartojimo prekes jis linkęs taupyti. Kita vertus, vartotojai nori pabrėžti savo socialinị statusą, todèl vartojimas tampa demonstratyvus. Internetinės prekybos dẻka vartojimo erdvė prasiplečia nuo vietinès rinkos iki globalios. Vartojimas auga atsiradus galimybei prekes ar paslaugas įsigyti išsimokètinai. Didelę ịtaką vartojimui daro aplinkiniai. Intensyvesni mainai tarp šalių, kultūrų ir pavienių asmenų visame pasaulyje skatina globalios kultūros plètrą. Kalbant apie turizmo vartotojų elgsena, nustatyta, kad vietoj ,vartojimo dèl vartojimo“ isigalejjo ,vartojimo, sukeliančio potyrius“ filosofija. Naujasis turistas apibūdinamas kaip išsilavinęs, patyręs, turintis daug didesnių lūkesčių nei bet kada anksčiau. Technologijų dèka jis daug žino ir sugeba prisitaikyti skirtingose kultūrinèse aplinkose. To pasekmé - didejja savarankiškai planuojamų kelionių skaičius, populiarèja elektroninis turizmas. Šių dienų miesto žmonės vis labiau vertina gamta, todèl išauga alternatyvaus turizmo reikšmè. Pagrindiniu keliavimo tikslu tampa naujos aplinkos ir patirties ieškojimas, susietas su ženklais, simboliais ir kultūra. Galima teigti, kad šių dienų turistas yra individualus, tad ji sunku priskirti kažkuriam tradiciniam segmentui.

Tyrimo rezultatai atskleide, kad pagrindinis Lietuvos gyventojų prioritetas (skirtingai nuo globalaus vartotojo) - materialinis saugumas. Lietuvoje vis dar vyrauja „daiktų era“. Lietuvos gyventojai svajoja apie keliones už Lietuvos ribų, tačiau iš tiesų keliauja labai nedidelè dalis gyventojų. Lietuvos teritorijoje keliaujama kur kas dažniau nei už Lietuvos ribų. Asmenims iki 50 m. išvykstamasis turizmas aktualesnis nei vietinis turizmas, nuo $51 \mathrm{~m}$. iki pensijos - kelionès Lietuvos teritorijoje, pensinio amžiaus žmonės linkę keliauti Lietuvos teritorijoje arba pramogauti savame mieste. Lietuvos gyventojai keliauja, nes finansiškai gali sau tai leisti, nėra linkę kelionėms skolintis pinigų iš draugų ar bankų. Daugeliui kelionės nėra gyvenimo tikslas, tradicija ar socialinio statuso išraiška. Kelionės Lietuvos gyventojams būtinos, siekiant atsipalaiduoti, pailsèti. Jaunimas ị keliones vyksta ieškodamas nuotykių. Moterys labiau linkusios taupyti, o vyrai - kelionėmis išreikšti savo socialinị statusą. Aukštesnị išsilavinimą turintys asmenys stengiasi įžvelgti mokslinès ir verslui palankios naudos, rinkdamiesi keliones taupo. Lietuvos gyventojai keliauja paskatinti aplinkinių arba susigundę geromis kainomis. Dažniausiai kelionės tikslu tampa netolimos, pigios ir plačiai populiarinamos šalys (Latvija, Lenkija, Vokietija, Italija, Prancūzija, Čekija, Estija). Lietuvos turistai yra taupūs, todẻl planuodami keliones ir rinkdamiesi apgyvendinimą ieško pigiausių alternatyvų. Vis dažniau ke- 
liones planuoja patys. Lietuvos gyventojai ekologiškam turizmui vis dar neteikia didelès reikšmès. Didžioji dalis respondentų teigè, kad kelionių po Lietuvą ir užsienį skaičius, pinigų suma, skiriama kelionèms, nekito, šių dienų situaciją lyginant su prieš kriziniu ir su kriziniu laikotarpiu. Taip pat nekito kelionių atstumai, trukmė, atostogų laikotarpis, kelionių užsakymas per agentūras, savarankiškas keliavimas, keliavimas nuosavu transportu. Kita vertus, tiesinės koreliacijos metodu nustatyta, kad augant BVP, užimtumui, darbo užmokesčiui, pajamoms ir infliacijai, turẻjo didèti ir kelionių i užsieni skaičius. Pabrangus būtiniausioms prekèms ir paslaugoms, Lietuvos gyventojai teigia ir toliau keliausią, tačiau rinksis pigesnes keliones.

PAGRINDINIAI ŽODŽIAI: vartotojas, vartotojo elgsena, darnus turizmas.

JEL KLASIFIKACIJA: O100, O110, L890 